\title{
The ethics of postmortem examinations in contemporary Islam
}

\author{
Vardit Rispler-Chaim University of Haifa, Israel
}

\section{Author's abstract}

Postmortem examinations have recently become common practice in Western medicine: they are used to verify the cause of death and to obtain additional scientific information on certain diseases, as well as to train medical students.

For religious people of the monotheistic faiths postmortems present several ethical questions even though the advantages attributed to postmortems in the West are also acknowledged by fews, Christians and Muslims.

The Islamic way of dealing with such questions will be surveyed via contemporary fatāwā (legal opinions) issued primarily by Egyptian scholars; Islamic law, which was formulated in the eighth to ninth centuries, did not speak of postmortems. I will therefore depict the means whereby contemporary scholars approach postmortems in the absence of clear legal reference.

The difficulties that postmortems create for Muslims at present will be weighed against some shar $\overline{1}$ instructions which may help circumvent them. While the ethical and religious debate continues, postmortems seem to be accepted but not, however, without certain reservations.

Much has been written in the 20th century on medical issues in their Islamic perspective, but very little on postmortems. However, in the second half of this century, the subject of postmortems has been discussed by Muslim scholars more than in the past, as it has by Western thinkers and by scholars of other religions too.

Due to the rapid development of medicine in the 20 th century and to its development of scientific methods, postmortems have become an efficient instrument with which to learn more of the causes of

\section{Key words}

Shar $a$ : Islamic law based on the Qur'an and Hadith (Oral Tradition); Shar $\bar{i}$ : belongs to Islamic law; fatwa (pl fatāwa) : a legal opinion, often expressed in a question/answer format; mufti : a religious scholar who issues legal opinions; $q \bar{a} d \bar{i}$ : a Muslim judge; mas laha: the principle of public benefit; Hanbalì/Shäfi $\bar{\imath} / M a \bar{a} i k i /$ Hanafi the four schools of law in Islam. death, and consequently of ways to postpone death in certain cases. In many modern states postmortems are mandatory in order to verify the cause of death; as such they have also proved helpful in solving homicides and in bringing about justice.

For religious people, postmortems may seem a desecration of the human body. For monotheists, at least, the body is viewed as God's property, entrusted to a human being for a limited period, after which it should be returned to God in the best condition possible. No changes, removals or additions are allowed. Therefore, we find nowadays that the medical ethics of Muslims, Jews and Christians have to deal, in addition to postmortems, with the following issues: Is it legitimate, according to their respective religions, to transplant body parts, to donate body parts and to reshape body parts - all are processes which obviously entail making changes in the human body.

Muslims often utilize the literary genre of the fat $\bar{a} w \bar{a}$ as a productive way of expressing the contemporary responses of well known scholars to 'new' questions; ie, questions for which there is no direct answer in the Qur'an and the Hadith (Oral Tradition), or in pre-20th century Islamic legal literature. The fatwa is a legal opinion issued by a reputable scholar. It is not a binding law. It is therefore normal to expect more than one opinion on a given question. For lay people this can complicate the act of choosing. In the long run, however, the multiplicity of opinions leaves room for manoeuvre and for the more liberal ideas to flourish, and is generally conducive to the future of religious life.

Since postmortems as an independent topic were not studied until the 20th century, and since currently when they are discussed, it is primarily in fatwas, these also serve as our main source of information. Some of these fatwas are short and succinct. Others are lengthy and loaded with indirect references to the topic. Both types are typical of fatwas dealing with issues on which the basic legal sources are silent. When a legal opinion is nevertheless required of the muftis, they resort to analogy, associative thinking and to their own value judgement, and new fatwas are thus created. 


\section{Contemporary fatāwā on postmortem examinations}

In 1910 the famous Egyptian scholar Rashīd Ridā (d 1935) published a fatwa entitled 'postmortem examinations and the postponement of burial' (1) which seems to have been the first treatment of the topic in this century. Then we find Makhlūf's fatwa of the 1940s, which debates the permission to perform postmortems for scientific and juridical purposes (2). The issue arose again in the $1980 \mathrm{~s}$ in response to the increasing use of postmortems in Western-style hospitals in Islamic and Arab countries. Ridāa's dealing with this subject thus remains unique, indeed remarkable, against the silence of most muftīs regarding postmortems during the first decades of the century. The fact that Ridā's fatwā was primarily of political import may partly explain his early interest in the subject. This political aspect will be mentioned below.

\section{The problematics of postmortems in Islamic law}

From the fatwas which deal with postmortem examinations and whether they can be legitimized by Islamic law, four central sub-questions emerge which represent the problematics of postmortems in Islamic law:

(a) Should a burial be postponed so that a postmortem may be conducted?

(b) Should a human body be transferred from place to place before its burial?

(c) Do postmortems involve a violation of the sanctity associated in Islamic theology with the human body?

(d) Is it permitted to perform postmortems for scientific purposes and for criminal identification?

\section{A) THE POSTPONEMENT OF BURIAL}

Since postmortems require time, burial must necessarily be postponed. This poses a problem for religious Muslims, since the Shar a encourages the burial of the dead as soon after death as possible, in order to bring the dead person closer to what God has prepared for him/her'. 'Abd Al-Halīm Mahmūd (d 1978), who was Sheik Al-Azhar in 1973-1978, states that any delay in burial is held against those responsible for it, and they are considered sinners. The only delay allowed is the time necessary for ablution and for the preparation of the body for burial (3).

Rida dwelt on the aspect of verifying that the person considered dead was indeed dead. To prevent tragic accidents in which an unconscious person might be mistaken for dead and be buried, Rid̄a agreed to a delay in burial so that a doctor's medical examination could take place. Aware that haste in burials may lead to fatal mistakes, Ridā allowed some extension of the time between death and burial (4). Ridā followed the same reasoning to conclude that when a non-Islamic government made a medical examination to verify death mandatory, thus causing a delay in burial, it should not be viewed as an anti-Muslim measure but should be appreciated and understood by Muslims as a welcome precaution. In other words, Muslims living in a non-Islamic state were not obliged to migrate to the Ottoman Empire, where Islamic law prevailed, to escape the law causing a delay in burial.

Rida showed that the secular law which contradicts a Shar $i$ ruling could be viewed even by Muslims as a positive measure if approached from a different angle: the postponement of burial may entail certain advantages, and these can supersede the Shar $i$ ruling to hasten burial.

The two somewhat contradictory opinions, by Ridā on the one hand and by Mahmūd on the other, can both claim support in the Shari a. On the one hand it is encouraged to hasten burial as an expression of respect for the dead and of bringing God's servant closer to Him (5). A prompt burial ensures that the body does not lose its human form before its burial, and hence its human dignity (6). It is also beneficial to the members of the community; if good fortune awaits the deceased, then the good deed of expediting the journey of the deceased to the Lor $\$$ could be credited to them, and if the deceased was bad person, better to free themselves of his/hes presence as soon as possible (7).

On the other hand, if death is not established absolutely and beyond any doubt it is recommended to act more cautiously. Al-Shāfí $\overline{1}$ (d 820), already in the second century of Islam, recommended waiting two or three days before burial when someone was believed dead as a result of drowning or being struck down in a storm. He explained that unconsciousness and shock were common to people caught in a storm, attacked by wild beasts, shattered by war or who had fallen off a cliff. If they did not regain consciousness in two or three days, they were probably dead (8). Ibn Qudāma limited the postponement until the usual physical signs of death appeared (9). The Shāfí $\overline{1}$ Ibn Hajar Al-Haythamī (d 1567) allowed a short delay in burial until camphor (käfür) to wash the deceased was obtained. The deceased, he claimed, deserved the best treatment (10). Hence precedents can be shown in Islamic law in which postponing burial in certain cases is not only permitted but recommended.

B) TRANSFERRING THE BODY FROM PLACE TO PLACE Postmortems also require the transfer of a body from the residence of the deceased or from the site of death to a laboratory or hospital where the examination can take place. This may cause a delay in burial and possibly also physical damage, which leads to desecration of the body.

In the Shari $a$ we indeed find that it is preferred to bury the dead at the site of their death or killing, ie, 
in the cemetery of the nearest community. Therefore, the Prophet ordered the interment of those slain in the battle of Uhud (625) near the battlefield, although the cemetery of the city of AlMadina was not too distant. For the same reason, the conquerors of Damascus were buried where they fell, and not all of them at one site (11). 'A $\overline{\text { isha, the }}$ beloved wife of the Prophet, condemned the transfer of her brother ${ }^{\mathrm{C}} \mathrm{Abd} \mathrm{Al}-\mathrm{Rahmmān} \mathrm{b}$ Abī Bakr, who died in Abyssinia, to Mecca, knowing that the long journey could cause a deterioration of the body (12).

Transferring the deceased a distance of one or two miles is acceptable to the Shari $a$, because most cemeteries are located that far from their respective towns (13). This Hanafi ruling is embraced by modern muftīs too (14).

Ahmad b Hanbal (d 855), however, permitted the transfer of the deceased any distance, if it was for 'a justified purpose' (12).

I could not find in contemporary fatāwa a direct reference to the permission to transfer the deceased immediately after death other than to a cemetery. Several fatāwa , however, mention the transfer of a body after it had already been buried. In one, the transfer was permitted in order to prevent the body from being submerged in a flood; in another, so that family members would be able to visit the grave more often (15). The third case involves Makhlūf's permission to transfer the remains of the last Ottoman sultan, 'Abd Al-Majīd, and his wife, who were embalmed and buried in France, to be reburied in Egypt. The reason given was that it was to the benefit of the deceased to be buried in an Islamic state (16). In all cases the ruling did not indicate licence to transfer remains generally but was an ad hoc solution to a specific problem.

In another fatw $\bar{a}$, the remains of the dead were allowed to be exhumed and transferred to a new cemetery, when the old one had not been in use for over a century, and the site was earmarked for construction of a mosque (17). Here the benefit of the community outweighs that of the deceased.

If an analogy can be applied here, the question is whether the opening of a grave to transfer a body to a different site, for any of the acceptable reasons listed, is more serious a matter than the transfer of newly deceased persons to a hospital for postmortems before they are buried. Needless to say, no such comparison has been made in contemporary fatāwā.

\section{C) VIOLATION OF THE SANCTITY OF THE BODY}

Any operation on a human body after death, and therefore not designed to cure some ailment, may fall into the category of desecration of the dead. This is the major problem that postmortems pose for religious people. Such examinations may at best benefit the living by contributing to their better understanding of the cause of death or date of death. The deceased cannot be helped by that. We must therefore consider if a postmortem is indeed a purposeless violation of the wholeness of the body.

Makhlüf admits that postmortems indeed involve a violation of the sanctity of the body. However, he resorts to the useful principle in Islamic theological reasoning that whenever benefits outnumber damages a positive approach should be taken (maslaha). Consequently, since postmortems result in more benefits than damages, the Shari $a$ may be in favour of them. Makhlüf relies on a previous fatwa on the same issue given by Sheikh Yūsuf Al-Dajawī, who also legitimized postmortems on the basis of maslaha. Al-Dajawi compared the case of violating human dignity in postmortems with the approved permission in the Shari $a$ to remove money from a dead person's belly. Analogously, Al-Dajawī concluded that in postmortems the injury to the body was more excusable and the benefit much greater (18).

Contrary to this, Sheik ${ }^{\mathrm{C}} \mathrm{Abd}$ Al-Fattāh stated that 'any harm done to the deceased, such as the sale of his/her body or part of it, is considered damage to his/her dignity, and this is a major sin' (19).

The Shari $a$ adheres to the principle that 'breaking the bone of a deceased is similar to breaking the bones of a living person'. Analogously, the removal of any part of a cadaver (as may be the procedure in certain postmortems) is forbidden. According to one opinion, even circumcision is considered removal of a body part and therefore illegitimate. The removal of gold from one's teeth after death is permitted only if this does not lead to loss of the tooth (20).

If a body part is found after the body has already been interred, that part should be washed separately and prayed for, and then buried beside the body in the same grave, although exposure of the body itself is not necessary.

A pregnant woman's belly should not be cut open when she dies, even when a living fetus is believed to exist. The fetus will be retrieved, if at all, by pressure applied by midwives on the belly or by their extraction of the fetus. If women are not available, men may not perform this task, and the mother will be left unburied until it is clear that the fetus is dead too. Only the Shäf ${ }^{\prime}{ }^{-}$''s permit the incision of the dead mother's belly to retrieve a living fetus, by analogy with the occasional permission to retrieve money from a deceased's belly (21), already mentioned. The Hanbalis view any attempt to rescue the fetus as a desecration of one human body for an unrealistic chance of saving another (19).

For all the reasons noted so far, the general Shar i position should be opposed to all postmortems. However, under one Shar $i$ maxim - 'needs render prohibitions permitted' - a pragmatic solution is reached: a postmortem may be performed on someone killed in a car accident when he/she is unidentified (22). Does anonymity guarantee that the speedy Islamic burial could not have been performed to begin with? Or that no relative may later claim that 
the dignity of the deceased was not properly maintained? An explanation is not provided, but this is at least a partial concession in the direction of legitimizing a few postmortems without violating Islamic law.

\section{D) SCIENTIFIC PURPOSES AND CRIMINAL}

\section{IDENTIFICATION}

Postmortems for purely scientific purposes or to obtain justice by correctly identifying the cause of death 'suffer' from all the above arguments: a delay in burial, the transfer of the body from one place to another before letting it rest in peace, and the possible violation of the integrity of the body. Yet the answer of the muftis is usually positive, based on balancing damages against benefits.

The Fatāwa Committee at Al-Azhar concluded in January 1982 that if medical students learn from postmortems, if justice prevails through them and if contagious diseases can be controlled through them, then benefits indeed outnumber damages, provided that these examinations are performed only when necessary (22).

Already in the beginning of the century, Ridā justified medical examinations of the dead to verify death, and was even ready to acquiesce to a foreign government's unacceptable law ordering it, at the expense of ignoring the general Islamic rule on the issue, in order not to run the fatal risk of burying a person alive (23).

Sheik ${ }^{\mathrm{C}} \mathrm{Abd}$ Al-Fattāh allowed postmortems for teaching purposes on an unidentified person killed in a car crash, relying on the same principle of 'needs render prohibitions permitted' (19).

On the same grounds, Makhlüf approved of postmortems which help to advance science and justice (18). Makhlūf even justified the donation of a body to science, either by the deceased himself/herself or through permission by a member of the deceased's family (24). This is an exceptional opinion for a leading religious scholar, especially considering the significance of burial for monotheists.

We may summarize the above by saying that although postmortems involve elements unacceptable to Islamic law the benefits they provide are now considered indispensable. The unacceptable elements are excused on the grounds of the pragmatic Islamic legal principle of 'the public benefit' (maslaha). The violation which may befall the body of an individual owing to postmortems is overlooked in order to enable science and justice, and consequently the public good, to prevail (25).

\section{Summary}

The subject of postmortem examinations in contemporary ethics should be viewed as part of the subject of medical ethics, which Islamic legal literature, prior to the 20th century, did not recognize and therefore did not discuss. The need to provide some moral evaluation of a 'newly' arising issue forces the muftīs to use tortuous mental exercises, logic and analogy, in order to attack the problem obliquely, since a straightforward answer is hardly possible. Makhlūfs fatwa illustrates the 'tortuous' method (18).

He was requested to opine on whether the Shari a is in favour of postmortem examinations for scientific and juridical purposes. As we have stated, the classical legal sources do not speak of postmortems at all. Makhlūf therefore starts with a lengthy praise for medicine and for the high esteem it was accorded in the Sharr a: people were encouraged to seek cures for their maladies, not to exhaust their bodies in religious duties if their health was thereby endangered, and doctors were held as mediators between God and the sick. The importance of being a doctor was sometimes even equated with the importance of fighting a jihäd (holy war). This leads Makhlüf to the conclusion that postmortems for the advancement of medical sciences fall within the general spirit of acceptance which the Shari $a$ has for medicine, and that postmortems help to educate young medical students to become better doctors.

Makhlūf does admit that some violation of the body of the deceased may occur, but he stipulates that the rights of the deceased should generally be respected, except for 'what the Shari a permitted' a statement which leaves room for exceptions. He also mentions several cases, which he may today consider 'precedents' for postmortems, of which the Shar $a$ spoke. These cases are not connected in the Shari $a$ to postmortems at all, but to other legal issues: retrieving a sum of money from a deceased's belly is related to the subject of debts which the deceased owes; retrieving a fetus from the body of a dead mother is connected to the topic of rescuing a human being or of the prolongation of life. Makhlüf, however, treats these cases as legal precedents for postmortems.

In his striving to legitimize postmortems Makhlūf does not neglect to refute a possible reactionary claim that medicine managed for centuries without postmortems, so why is a change necessary at all. $\mathrm{He}$ explains that modern medicine relies on postmortems as well as on science and technology, thus stressing the urge that Islamic medicine should not fall behind Western medicine. This is a very useful argument in contemporary Islamic society, which is extremely sensitive to criticism of its lack of progress and inability to adapt to new conditions.

Makhlūf joins here other muftīs such as Sheikh Bakhīt of Egypt (26) and Sheikh Ibrāhīm Al-Ya qūbī of Syria (27). Both refuted another reactionary claim that via the autopsy of animals we can learn enough of the human body, and since all 'animals' are built alike, postmortems on humans are unnecessary.

In the end, Makhlüf, like the other muftis who ponder postmortem examinations, legitimizes it. 
The muftis vary in their respective literary styles and in the number of arguments they adduce to lead the reader to the bottom line. It could be argued that the result, ie, legitimization of postmortems based on pragmatism, could have been expected. This is probably true by inference from other contemporary medical ethics (28). However, the 'customers' of the fatäwa are devout Muslims, and they need to see the fatwa officially printed in order to be reassured that when they agree to postmortems they do not violate the Shari $a$ and therefore still remain within the boundaries of legitimate moral conduct of Muslims.

\section{Acknowledgement}

I wish to thank the Social Science Research Council of America for providing me with the opportunity to discuss some aspects of this article at a workshop in Granada, Spain.

Vardit Rispler-Chaim, $P h D$, has been a lecturer at the University of Haifa, Israel in the Department of Arabic since 1985. Her specialty is Islamic law, with emphasis on its adjustment to changing circumstances. Her teaching and research include topics such as human rights, medical ethics, insurance practices in the past and present and social issues in Islam.

\section{References and notes}

(1) Al-Manār 1910, v 13: 100-102.

(2) Makhlūf, H M. Fatāwa Shar iyya wa Buhūth Islāmiyya, Cairo: Dār Al - Kātib Al- ${ }^{\complement} \mathrm{Arabī}, 1952$ : 219-224. Makhlūf was born in Cairo in 1890, appointed qadi in 1916, head of the Shar 1 Court in Alexandria in 1941 and chief Muftī of Egypt in 1945. From 1948 he also served as a member of the Supreme Council of Scholars at Al-Azhar (the University for Islamic Studies in Cairo). (d 1990).

(3) Fatāwā 'Abd Al-Halīm Mahmūd, Cairo: Dār AlMa ārif 1986 v 2: 277.

(4) Fatāwā Rashīd Rid̄ā, Beirut: Dār Al - Kitāb Al Jadīd 1970 v 3: 851-853.

(5) Al - Turkmān̄i Al - Hanafī (14th century) Kitāb AlLuma Cairo: Franz Steiner Verlag Weisbaden
GMBH v 1: 219. Ibn Qayyim, Zād $A l-M a^{\mathrm{c}} \bar{a} d$ Cairo: $\mathrm{Al}$ - Bābī Al - Halabī 1970 v 1: 171.

(6) Ibn Qudāma, Al-Mughñ̄ Beirut: Dār Al - Kitāb Al'Arab̄i 1972 v 2: 307.

(7) Ibn 'Abidīn (d 1889) Häshiyat Radd Al-Muhtār Beirut: Dār Ihyā̄ Al-Turāth Al-'Arabī 196 v 1: 597.

(8) Al-Shāfici ${ }^{\complement}$, Kitāa Al-Umm Cairo: Maktabat AlKulliyyāt Al-Azhariyya 1961 v 1: 277.

(9) Al-Mughñ̄ v 2: 208.

(10) Ibn Hajar Al-Haythamī, Al-Fatāwā Al-Kubrā AlFiqhiyya Cairo: 'Abd Al-Hamīd Ahmad Hanafĩ 1938 v 2: 2 .

(11) Ibn 'Abidīn, Hāshiyat Radd Al-Muhtār v 1: 602.

(12) Ibn Qudāma, Al-Mughnī v 2: 390.

(13) Ibn- 'Abidīn, Hāshiyat Radd Al-Muhtār v 1: 602.

(14) Al-Nür 1991 Mar 13: 7.

(15) A fatwā issued by Sheikh ${ }^{\mathrm{A}} \mathrm{Abd} \mathrm{Al}-\mathrm{Haki} m \mathrm{Na}{ }^{\mathrm{C}} \overline{\mathrm{a}}^{\mathrm{c}}$ in Al-fumhüriyya 1984 Aug 13: 7 and a fatwā issued by 'Abd Al-Hamīd Al-Sayyid Shāhīn and 'Alī Hāmid 'Abd Al-Rahīm in Majallat Al-Azhar 1988 Sept-Oct: 183-184.

(16) Al-Liwwä aAL-Islämī 1991 Sept 12: 8.

(17) The fatwa was published both by ${ }^{\circ}$ Abd al-Hamid Alsayyid Shāhin and Safwat ${ }^{\circ}$ Abd Al-Fawäd in Majallat Al-Azhar 1988 Aug-Sept: 84.

(18) Fatāwā Shar ìya wa Buhūth Islämiyya: 219-224.

(19) Al-Ahrām 1983 Apr 15: 13.

(20) Ibn Qudāma, Al-Mughn̄̄ v 2: 326.

(21) See reference (20): 413.

(22) Majallat Al-Azhar 1982 Jan: 650.

(23) Fatāwā Rashīd Ridā v 3: 851-853.

(24) Al-Ahrām 1983 Jan 26: 13.

(25) Sheikh Ibrāhīm Al-Waqfĩ in Al-Liwwā Al-Islāmī 1991 Aug 22: 7.

(26) Majallat Al-Azhar 1935 v 6: 627-633.

(27) Shifā $\supset$ Al-Ta ${ }^{\supset}$ rìkh wal Adwā ${ }^{\supset}$ fì Hukm Al-Tashrīh wal $A^{\wedge} d \vec{a} \rightarrow$ : Damascus, 1986.

(28) Rispler-Chaim V. Islamic medical ethics in the 20th century. Fournal of medical ethics 1989; 15: 203-208.

\section{Short bibliography}

Ghanem I. Islamic medical jurisprudence. London: Probsthain, 1982. Islamic Code of Medical Ethics. Kuwait: Al-Munazzama Al - 'Alamiyya Iil-Tibb Al-Islāmī, 1981 (Document of the 1st International Conference on Islamic Medicine). 